\title{
Informed community mobilization for dengue prevention in households with and without a regular water supply: Secondary analysis from the Camino Verde trial in Nicaragua
}

\author{
Alvaro Cárcamo ${ }^{1}$, Jorge Arostegui ${ }^{1 *}$, Josefina Coloma², Eva Harris², Robert J. Ledogar ${ }^{3}$ and Neil Andersson ${ }^{4,5}$
}

From The Camino Verde Trial colloquium

Acapulco, Mexico. 17-21 June 2013

\begin{abstract}
Background: Studies in different countries have identified irregular water supply as a risk factor for dengue virus transmission. In 2013, Camino Verde, a cluster-randomised controlled trial in Managua, Nicaragua, and Mexico's Guerrero State, demonstrated impact of evidence-based community mobilisation on recent dengue infection and entomological indexes of infestation by Aedes aegypti mosquitoes. This secondary analysis of data from the trial impact survey asks: (1) what is the importance of regular water supply in neighbourhoods with and without the trial intervention and (2) can community interventions like Camino Verde reasonably exclude households with adequate water supply?

Methods: Entomological data collected in the dry season of 2013 in intervention and control communities allow contrasts between households with regular and irregular water supplies. Indicators of entomological risk included the House Index and pupa positive household index. Generalised linear mixed models with cluster as a random effect compared households with and without regular water, and households in intervention and control communities.

Results: For the House Index, regular water supply was associated with a protection in both intervention households (OR 0.7, 95\% $\mathrm{Cl} 0.6-0.9$ ) and control households (OR 0.6, 95\% Cl 0.5-0.8). For the pupa positive household index, we found a similar protection from regular water supply in intervention households (OR 0.6, $95 \% \mathrm{Cl} 0.4-0.8)$ and control households (OR $0.7,95 \% \mathrm{Cl} 0.5-0.9)$. The Camino Verde intervention had a similar impact on House Index in households with regular water supply (OR $0.7,95 \% \mathrm{Cl} 0.5-1.0)$ and irregular water supply (OR 0.6, 95\% Cl 0.4-0.8); for the pupa positive household index, the effect of the intervention was very similar in households with regular (OR0.5, 95\% $\mathrm{Cl} 0.3-0.8)$ and irregular (OR 0.5, 95\% Cl 0.3-0.9) water supply.

* Correspondence: ciet@cablenet.com.ni

${ }^{1}$ CIET Nicaragua, Managua, Nicaragua

Full list of author information is available at the end of the article 
(Continued from previous page)

Conclusion: While Aedes aegypti control efforts based on informed community mobilisation had a strong impact on households without a regular water supply, this intervention also impacted entomological indices in households with a regular water supply. These households should not be excluded from community mobilisation efforts to reduce the Aedes aegypti vector.

Trial registration: ISRCTN27581154.

Keywords: Water supply, Aedes aegypti, Intermittent water supply

\section{Background}

Water is a necessary condition for health, but also a route for disease transmission [1], mainly when there are supply problems. Many urban centres lack adequate water supply, with services available only for a limited time or in restricted areas of the city. This makes household water storage necessary to meet needs when the service is unavailable [2]. In Managua, household water is stored mainly in barrels, but also in buckets and jugs. The stored water is used for personal hygiene, cooking and household cleaning chores. One risk of these water stores is that improperly handled containers become favourable environments for the eggs, larvae and pupae of the Aedes aegypti mosquito, resulting in an increase of new adult mosquito populations.

Several studies have explored the links between water supply, Aedes aegypti ecology and dengue transmission risk. A 1992 study in Venezuela's coastal region showed interruptions of the water supply were associated with more Aedes aegypti larvae and pupae in water storage containers [3]. Another study in Maracay, Venezuela, showed adequate water supply was a protective factor against dengue [4]. A 2005 anthropological study in Fortaleza, Brazil, pointed to water supply affecting Aedes aegypti ecology [5]. A 2010 cohort study of 75,000 households in Vietnam linked frequency of water supply and population density with dengue transmission risk [6].

Managua, Nicaragua's capital and main commercial and service centre, is less than $100 \mathrm{~m}$ above sea level. Its tropical climate reaches $38^{\circ}$ Celsius during the warmest seasons [7]. The National Water and Sewerage Company (ENACAL, Empresa Nacional de Acueductos y Alcantarillados) runs and manages the system distributing water to 1.5 million residents [8]. According to ENACAL data, the water distribution network reached a nominal $94 \%$ of Managua's population in 2012 [9]. However, hourly coverage deficiencies result from planned service outages and technical or operational problems in the network. Understanding of the system's effective coverage requires information from householders themselves. The water supply is affected by topography, so may be regular for some households and irregular for others within the same neighbourhood.

Between 2010 and 2013, the Camino Verde (Green Way) randomised controlled trial in Managua and
Guerrero State, Mexico, reported a significant impact of informed community mobilization on Aedes aegypti larvae and pupae counts [10]. We present here a secondary analysis of data from the impact survey of the trial in Managua in the 2013 dry season, addressing two questions: 1) what is the importance of regular water supply in neighbourhoods with and without the trial intervention and 2) can community interventions like Camino Verde safely exclude households with adequate water supply?

\section{Methods}

In the trial impact survey in the 2013 dry season, field teams visited households in 60 neighbourhoods (30 intervention and 30 control). This article uses data obtained from all 60 neighbourhoods during this survey.

\section{Entomology inspections}

Six field teams of 12 workers each carried out the household survey, which included entomological inspections. Each team included five entomological reviewers and two supervisors, one of whom either had responsibilities in the vector control programme of the local healthcare system (known by its Spanish acronym as the SILAIS) or was an entomologist in the Ministry of Health's National Diagnostics and Reference Centre (CNDR). The entomological review applied the protocol and techniques standardised by the vector control programme for collecting, transporting, conserving, identifying, counting and classifying immature Ae. aegypti specimens at different stages of development. Each reviewer inspected every water container in each household to detect and to capture larvae and pupae. They classified containers as barrels or large tubs, buckets, washtubs, plant pots, flower pots, tyres, non-storage containers (pails, drinking fountains, etc.), and discarded household items that could hold water (calaches).

\section{Handling of specimens}

The inspectors placed all larvae or pupae in labelled jars containing $70 \%$ alcohol; they transferred the jars to the CNDR entomology laboratory, where a team of specialised entomologists verified and classified the specimens. Receptacles were classified positive when CNDR evaluators found one or more immature forms of mosquito at 
any stage of development. The entomology team also counted the collected specimens and classified them by stage of development, as an indicator of each container's mosquito productivity.

\section{Outcomes}

We calculated two entomological indices, one to reflect all immature forms and one to reflect just pupae. The House Index (HI) is the proportion of households positive for larvae or pupae. We classified a household as positive for pupae if the entomology lab confirmed the presence of one or more pupae in that household. Because the exposure of interest was household water supply (see below), the Breteau, container and pupae per person indices could not be applied in their original form.

\section{Exposure}

Our measure of regularity of water supply came from answers to the question "How many times did the household lack water in the last week?" We classified water supply as "regular" if a household had continuous access to water or lacked it for no more than a day during the week prior to the survey. We classified households reporting no water supply for two or more days in the week prior to the survey as having "irregular" water supply.

\section{Statistical analysis}

The Camino Verde trial used cluster as the unit of principal analysis [10]. This secondary analysis used household as the unit because regularity of water supply was not uniform within the clusters. Bivariate and then multivariate analysis evaluated impact of regularity of water supply on each entomological index, in the context of other factors that might affect the outcome, derived from household responses to an administered questionnaire. Sensitivity analysis for the outcome of pupae positive households converted the continuous variable of regularity of water supply into a binomial variable by categorizing at two additional points, and rerunning the models.

Bivariate analysis examined the association between the two entomological indicators as outcomes, and exposure to regular water supply, as well as other variables potentially related to the outcomes, derived from household responses. We included variables significant at the $5 \%$ level in bivariate analysis (essentially temephos and water supply) in a saturated generalised linear mixed model (GLMM) with cluster as a random effect. We developed separate models for intervention and control sites to assess the importance of water supply in relation to informed community mobilisation. To address the overall importance of the intervention, we developed separate models for regular and irregular water supply, with cluster as a random effect. We report the odds ratio
(OR) and protection (1-OR) from these analyses, along with the number needed to treat (NNT). The analysis used the Zelig programme in $\mathrm{R}$ through CIETmap, an open-source package that provides an interface with the $\mathrm{R}$ statistical programming language [11]. We used the Zelig default burn-in, discarding the first 1000 iterations.

\section{Results}

Among all households for which we had water supply data in January $2013(n=8121), 50 \%$ had continuous access to water or lacked it for no more than a day during the week prior to the survey (regular water, 4075/8121) and the other half reported interruption of water supply for two or more days in the week prior to the survey ("irregular" water, 4046/8121). Data on water supply were missing from 15 households, which were excluded from the analysis. The rates of regular supply were similar in intervention (2041/4046) and control (2034/4075) neighbourhoods.

\section{Effect of water supply in intervention and control households}

Households with an irregular water supply were roughly twice as likely to have a positive House Index and to be pupae-positive compared with households with a regular supply (Table 1). Having regular water was associated with a protection (1-OR) of $30 \%$ for the House Index and $40 \%$ for the pupae-positive household index. For both entomological outcomes, the effect of regularity of water supply was similar in intervention and control households (Tables 2 and 3). Contrasting with the similar odds ratio in intervention and control households, the number needed to treat (with a regular water supply) was quite different in intervention and control neighbourhoods: to prevent one household having a positive Household Index (any larvae or pupae) in each neighbourhood, 29 intervention households or 14 control households would need to be provided with a regular water supply. To convert one household from pupaepositive to pupae-negative in intervention and control neighbourhoods, 46 intervention households or 33 control households would need to be provided with a regular water supply.

Table 1 Entomological indices and regularity of water supply, Managua, January 2013

\begin{tabular}{|c|c|c|c|c|c|}
\hline \multirow[t]{2}{*}{ Water supply } & \multirow[t]{2}{*}{ No. households } & \multicolumn{2}{|l|}{ House Index ${ }^{a}$} & \multicolumn{2}{|c|}{ Pupae } \\
\hline & & $\begin{array}{l}\text { Positive } \\
\text { households }\end{array}$ & $\begin{array}{l}\text { House } \\
\text { Index (\%) }\end{array}$ & $\mathrm{N}$ & $\begin{array}{l}\text { Mean per } \\
\text { household }\end{array}$ \\
\hline Regular & 4075 & 565 & 14 & 1314 & 0.3 \\
\hline Irregular & 4046 & 968 & 24 & 3496 & 0.9 \\
\hline
\end{tabular}

${ }^{\mathrm{a}}$ House Index = percent of houses infested with larvae and/or pupae 
Table 2 House Index in households with regular and irregular water supply, in intervention and control sites, Managua, January 2013

\begin{tabular}{|c|c|c|c|c|c|}
\hline \multirow[t]{2}{*}{ Water supply } & \multicolumn{2}{|l|}{ Intervention sites } & \multicolumn{2}{|l|}{ Control sites } & \multirow{2}{*}{$\begin{array}{l}\text { Impact of intervention } \\
\text { OR }(95 \% \mathrm{Cl} \text { of OR); NNT } \\
(95 \% \mathrm{Cl} \text { of NNT) })^{\mathrm{a}}\end{array}$} \\
\hline & No. households & $\begin{array}{l}\text { No. (\%) positive } \\
\text { for larvae/pupae }\end{array}$ & No. households & $\begin{array}{l}\text { No. (\%) positive } \\
\text { for larvae/pupae }\end{array}$ & \\
\hline Regular supply & 2028 & $243(12)$ & 2031 & $396(20)$ & $0.7(0.5-1.0) ; 24(12-251)$ \\
\hline Irregular supply & 2015 & $322(16)$ & 2016 & $572(28)$ & $0.6(0.4-0.8) ; 11(7-36)$ \\
\hline \multicolumn{6}{|c|}{ Association with regularity of water supply: OR ( $95 \% \mathrm{Cl}$ of OR); NNT ( $95 \% \mathrm{Cl}$ of NNT) ${ }^{\mathrm{a}}$} \\
\hline All sites & \multicolumn{2}{|l|}{ Intervention sites } & \multicolumn{2}{|l|}{ Control sites } & \\
\hline $0.7(0.6-0.8) ; 19(13-35)$ & \multicolumn{2}{|c|}{$0.7(0.6-0.9) ; 29(16-103)$} & \multicolumn{2}{|c|}{$0.6(0.5-0.8) ; 14(9-24)$} & \\
\hline
\end{tabular}

${ }^{\mathrm{a} O d d s}$ Ratio and 95\% confidence interval; number needed to treat and 95\% confidence interval. Both OR and NNT from GLMM, with cluster as random effect. In addition to regularity of water supply or intervention status, observed presence of temephos remained in the final models

\section{Informed community mobilisation in households with regular and irregular water supply}

We examined the impact of the informed community mobilisation intervention on Aedes aegypti larvae and pupae in separate models by water supply, again with cluster as a random effect in the GLMM (Tables 2 and 3). The Camino Verde intervention had a similar protective impact on Household Index in households with regular (OR 0.7, 95\%CI 0.5-0.1) and irregular (OR 0.6, 95\%CI 0.4-0.8) water supply; for the pupa positive household index, the effect of the intervention was very similar in households with regular (OR0.5, 95\%CI 0.30.8 ) and irregular (OR 0.5, 95\%CI 0.3-0.9) water supply. For both entomological outcomes, however, the NNT was lower in households with irregular water supply (Tables 2 and 3): the Camino Verde intervention would need to reach 11 households (95\% CI 7-36) with irregular water supply or 24 households (95\% CI 12-251) with regular water supply to prevent one household having a positive House Index; to reduce the pupa index in one house, the intervention would need to include 30 houses with regular water and only 22 with irregular water.

A sensitivity analysis looked at different cut-off points of water supply regularity. Moving the cut-off one place to the right (less stringent) in a range of $1-5$ produced an odds ratio of 0.6 and First Difference of 0.026; moving it one place to the left (more stringent) produced an odds ratio of 0.6 and First Difference of 0.025 . The result of the cut-off used in the analysis was an odds ratio of
0.6 and First Difference of 0.028 , implying the cut-off point does not account for a spurious result.

\section{Discussion}

Confirming findings of other studies, our results indicate a roughly twofold increased risk for entomological evidence of Aedes aegypti infestation in households with irregular water supply compared with those that have regular water supply. Water supply affected entomological risk in both intervention and control clusters in the Camino Verde trial. Our study shows that regular water supply is an important aspect of vector ecology and mosquito control, with or without community mobilisation. The numbers of water storage containers kept by the households reflected within-neighbourhood variations in water supply.

Solving problems of water supply requires medium- and long-term investments. Meanwhile, households obliged to store water should prevent mosquitoes from using their storage containers to reproduce. The community mobilisation intervention of Camino Verde reduced Aedes aegypti indices in households with regular water supply as well as those with irregular water supply.

The informed community mobilization, aimed at reducing mosquito breeding sites in and around households, made a significant difference to households that reported regular water supply, but it did not eliminate entomological risk. A possible explanation is that "regular" supply was not adequate for all household needs. We found

Table 3 Pupa positive households with regular and irregular water supply, in intervention and control sites, Managua, January 2013

\begin{tabular}{|c|c|c|c|c|c|}
\hline \multirow[t]{2}{*}{ Water supply } & \multicolumn{2}{|l|}{ Intervention sites } & \multicolumn{2}{|l|}{ Control sites } & \multirow{2}{*}{$\begin{array}{l}\text { Impact of intervention* } \\
\text { OR ( } 95 \% \mathrm{Cl} \text { of OR); } \\
\text { NNT ( } 95 \% \mathrm{Cl} \text { of NNT) }\end{array}$} \\
\hline & No. households & No. (\%) positive for pupae & No. households & No. (\%) positive for pupae & \\
\hline Regular supply & 2028 & $76(4)$ & 2031 & $135(7)$ & $0.5(0.3-0.8) ; 30(18-83)$ \\
\hline Irregular supply & 2015 & $148(7)$ & 2016 & $248(12)$ & $0.5(0.3-0.9) ; 22(12-77)$ \\
\hline
\end{tabular}

Association with regularity of water supply: OR ( $95 \%$ Cl of OR); NNT (95\% Cl of NNT)

$\begin{array}{lll}\text { All sites } & \text { Intervention sites } & \text { Control sites } \\ 0.6(0.5-0.8) ; 40(28-84) & 0.6(0.4-0.8) ; 46(26-134) & 0.7(0.5-0.9) ; 32(19-85)\end{array}$

*Odds Ratio and 95\% confidence interval; number needed to treat and 95\% confidence interval. Both OR and NNT from GLMM, with cluster as random effect. In addition to regularity of water supply or intervention status, observed presence of temephos remained in the final models 
water storage barrels in $9 \%$ of households that reported "regular" water supply. These households may not have had full confidence in their water supply and therefore kept water barrels for emergencies. Furthermore, households with a regular water supply still have a risk of dengue from other dynamics. They live close to neighbouring households and may be in range of the adult mosquitoes propagated there. Aedes aegypti is also active in daylight hours; people can be exposed as they move out of immediate home and neighbourhood environments where control is adequate [12].

\section{Limitations}

Entomology inspection teams did not participate in the trial intervention, but we cannot exclude the possibility they became aware of which households were in intervention and which in control clusters. Since we used household as the unit of analysis, to match the household water supply, we could not analyse the relationship with containers (Breteau and Container Index) or population density (pupa per person). The two indicators we could use in a household analysis reflected either all immature forms (House Index) and or pupae specifically (Pupae-positive households). Dichotomising variables can introduce problems of interpretation, especially if a negative result could be an effect of an arbitrary dichotomy. Our interpretation hinges on the fact the same dichotomy was used for all subgroups. Our sensitivity analysis with additional cut-off points for water supply regularity obtained substantively the same results as the main analysis.

\section{Conclusion}

While Aedes aegypti control efforts based on informed community mobilisation might prioritise communities with difficulty accessing a regular water supply, the intervention also impacts entomological indices of households with a regular water supply. These households should not be excluded from community mobilisation efforts to reduce the Aedes aegypti vector.

\section{Abbreviations}

CNDR: Centro Nacional de Diagnóstico y Referencia (National Diagnostics and Reference Centre at the Ministry of Health); ENACAL: Empresa Nacional de Acueductos y Alcantarillados (National Water and Sewage Company); SILAIS: Sistema Local de Atención Integral en Salud (Public health service for the Department of Managua)

\section{Acknowledgements}

We wish to thank the leaders and residents of the 60 Managua communities that participated in the Camino Verde trial. We also thank the members of the Entomology Laboratory of the CNDR and staff of the SILAIS Managua.

\section{Funding}

The UBS Optimus Foundation provided funding for the Camino Verde trial and the publication of this article.
Availability of data and materials

No additional data available.

\section{Authors' contributions}

AC and JA prepared the Spanish draft of this article. JA was lead researcher in the Nicaragua feasibility study and trial and contributed to the trial design and analysis; JC contributed to the drafting of this article and was a coinvestigator in the Nicaragua feasibility study; RJL contributed to the trial design and drafting of this article. NA was principal investigator of the Camino Verde trial and contributed to the drafting of this article. All authors read and approved the final manuscript.

\section{Competing interests}

The authors declare that they have no competing interests.

Consent for publication

Not applicable.

\section{Ethics approval and consent to participate}

This study was approved by institutional review boards at the University of California, Berkeley (22 July 2010), the Nicaraguan Ministry of Health (25 Auqust 2010), and CIETinternational (1 August 2010). Verbal consent was obtained from all participants.

\section{About this supplement}

This article has been published as part of BMC Public Health Volume 17 Supplement 1, 2017: The Green Way to Aedes aegypti mosquito control: aspects and implications of the Camino Verde trial in Mexico and Nicaragua. The full contents of the supplement are available online at https://bmcpublichealth. biomedcentral.com/articles/supplements/volume-17-supplement-1.

\section{Publisher's Note}

Springer Nature remains neutral with regard to jurisdictional claims in published maps and institutional affiliations.

\section{Author details}

${ }^{1}$ CIET Nicaragua, Managua, Nicaragua. ${ }^{2}$ Division of Infectious Diseases and Vaccinology, School of Public Health, University of California, Berkeley, Berkeley, CA, USA. ${ }^{3} \mathrm{CIET}$ International, New York, NY, USA. ${ }^{4}$ Centro de Investigación de Enfermedades Tropicales, Universidad Autónoma de Guerrero, Acapulco, Mexico. ${ }^{5}$ Department of Family Medicine, McGill

University, Montreal, Canada.

Published: 30 May 2017

\section{References}

1. Organización Panamericana de Salud. Salud en las Américas, Edición de 2012: Volumen Regional. Capitulo 3: Medio ambiente y seguridad humana 2012. http:// www.paho.org/saludenlasamericas/index.php?option=com_docman\&task=doc details\&gid=164\&ltemid=125\&lang=es. (Accessed 2 May 2017).

2. Milanés García Y. El abastecimiento intermitente de agua potable. Primera parte: una aproximación inicial a la dinámica del problema Available from: http://www.monografias.com/trabajos-pdf/abastecimiento-agua-potable/ abastecimiento-agua-potable.pdf. (Accessed 2 May 2017).

3. Barrera R, Navarro JC, Mora Rodriguez JD, Dominguez D, González Garcia JE. Deficiencia en servicios públicos y cría de Aedes aegypti en Venezuela. Bol Oficina Sanit Panam. 1995;1 18:410-23.

4. Cáceres JL, Giovinco L, Ruben M, Rondón R, Diaz MJ, Rojas V. Factores asociados a infección por virus dengue en menores de 15 años de edad. Maracay Venezuela 1997. Boletin de Malariologia y saneamiento ambiental, 2002; XLII: 13-16 Available from: www.iaes.edu.ve/descargas/ Boletn\%20de\%20Malariologa\%20y\%20Salud\%20Ambiental/N42-N1-N2-2002/ 02_factores_asociados.pdf. (Accessed 2 May 2017).

5. Caprara A, de Oliveira Lima JW, Marinho AMCP, Gondim Calvasina P, Paes Landim L, Sommerfeld J. Irregular water supply, household usage and dengue: a biosocial study in the Brazilian northeast. Cad Saúde Pública. 2009;25(suppl.1):S12536. http://dx.doi.org/10.1590/S0102-311X2009001300012. (Accessed 2 May 2017).

6. Schmidt W-P, Suzuki M, Thiem VD, White RD, Tsuzuki A, Yoshida L-M, et al. Population density, water supply and risk of denque fever in Vietnam: cohort study and spatial analysis. PLoS Med. 2011;8:e1001082. 
7. Características generales del municipio de Managua. Available at: https://es. wikipedia.org/wiki/Departamento_de_Managua. (Accessed 2 May 2017).

8. Stockholm Environmental Institute Informe final ambiental programmea de agua y saneamiento de Managua desde 2007 al 2010. Stockholm Environmental Institute, 2010. Available at: http://www.ecosanres.org/pdf_ files/Nersion\%20final\%20Saneamiento\%2029\%20Nov\%202010Fotos.pdf. (Accessed 2 May 2017).

9. ENACAL. Plan de desarrollo institucional de ENACAL 2008-2012. Available at: www.enacal.com.ni/informacion/Wc89973b236e289.htm. (Accessed 2 May 2017).

10. Andersson N, Nava-Aguilera E, Arosteguí J, Morales-Perez A, Suazo-Laguna $\mathrm{H}$, Legorreta-Soberanis J, et al. Evidence based community mobilization for dengue prevention in Nicaragua and Mexico (Camino Verde, the green way): cluster randomized controlled trial. BMJ. 2015;351:h3267.

11. Choirat C, Honaker J, Imai K, King G, Lau O. Zelig: Everyone's Statistical Software. Version 5.0-15, 2017. http://zeligproject.org/. (Accessed 2 May 2017).

12. Reiner RC Jr, Achee N, Barrera R, Burkot TR, Chadee DD, Devine GJ, et al. Quantifying the epidemiological impact of vector control on dengue. PLoS Negl Trop Dis. 2016;10:e0004588. doi:10.1371/journal.pntd.0004588.

\section{Submit your next manuscript to BioMed Central} and we will help you at every step:

- We accept pre-submission inquiries

- Our selector tool helps you to find the most relevant journal

- We provide round the clock customer support

- Convenient online submission

- Thorough peer review

- Inclusion in PubMed and all major indexing services

- Maximum visibility for your research

Submit your manuscript at www.biomedcentral.com/submit 